\begin{tabular}{lcc}
\hline International Journal of Current Research in \\
Biosciences and Plant Biology \\
\hline EXCELLENT \\
PUBLISHERS
\end{tabular}

Original Research Article

doi: https://doi.org/10.20546/ijcrbp.2018.501.004

\title{
Comparison in Growth Parameters of the Bacterization Effect on Axonopus affinis Seeds and EDTA against Cadmium
}

\section{Daniel Corona-Álvarez ${ }^{1}$, Leonor Angelica Guerrero-Zúñiga ${ }^{1}$ and Angelica Rodríguez-Dorantes ${ }^{2 *}$}

\author{
1Instituto Mexicano del Petróleo, México City 07730, México \\ 2Laboratorio de Fisiología Vegetal, Departamento de Botánica, Escuela Nacional de Ciencias Biológicas, \\ Instituto Politécnico Nacional, México City 11340, México
}

*Corresponding author.

\begin{tabular}{|c|c|}
\hline Article Info & \multirow{5}{*}{$\begin{array}{l}\text { The most evident effects of toxic compounds on plants are the inhibition of seed } \\
\text { germination and root growth. Microorganisms and chelating agents are two viable } \\
\text { options to assist phytoextraction of heavy metals. This study analyzed the effect of } \\
\text { bacterization of carpet grass (Axonopus affinis) seeds with a plant growth promoting } \\
\text { rhizobacteria and EDTA on germination and seedlings response in presence of } \\
\text { cadmium. The analysis done of Axonopus affinis by its morphological determinations } \\
\text { showed that the effect of these assisted phytoextraction agents someway inhibited } \\
\text { and/or promoted the first stage of development in this plant species; these results } \\
\text { demonstrated that the presence of rhizobacteria maintained the growth of seedlings } \\
\text { and tolerated the presence of the metal, including the adverse effects of EDTA; } \\
\text { suggesting a synergistic effect between microorganism and plant species tested. }\end{array}$} \\
\hline $\begin{array}{l}\text { Date of Acceptance: } \\
25 \text { December } 2017\end{array}$ & \\
\hline $\begin{array}{l}\text { Date of Publication: } \\
\text { 06 January } 2018\end{array}$ & \\
\hline Keywords & \\
\hline $\begin{array}{l}\text { Axonopus affinis } \\
\text { Cadmium } \\
\text { EDTA } \\
\text { Phytotoxicity } \\
\text { Rhizobacteria }\end{array}$ & \\
\hline
\end{tabular}

\section{Introduction}

The most widely used acute phytotoxicity tests involving vascular plants are the seed germination test and the root elongation test; simplest methods of environmental biomonitoring and most sensitive processes to analyze the heavy metal toxicity, because the lack of defense mechanisms as primary contact to metals (Wang and Keturi, 1990; Wang and Williams, 1990; Öncel et al., 2000; Araùjo et al., 2001; Munzuroglu and Geckil, 2002; Li et al.,
2005; Mahmood et al., 2007; Di Salvatore et al., 2008; Soudek et al., 2010; Visioli et al., 2014). In order to enhance the availability of heavy metals and its translocation from root to shoot, a variety of chelating agents have been investigated (Evangelou et al., 2007), but one of the most studied is ethylene diamine tetra acetic acid, EDTA (Grčman et al., 2001). It possess the ability to sequester metal ions such as $\mathrm{Fe}^{3+}, \mathrm{Cd}^{2+}$ and $\mathrm{Pb}^{2+}$, among others; after being bound by EDTA, metal ions remain in solution but exhibit diminished reactivity and with 
it, this salt is important in biological system acting as chelating agent. Particularly, the EDTA complex stablished with $\mathrm{Cd}$ reduces its uptake by plants (Agbadah et al., 2016). Microorganisms have gained the attention for their possible role in extracting metals from polluted soil, and most importantly better plant-microbe interaction in contaminated environments as a way to increase metal extraction (Khan and Lee, 2013; Ahmad et al., 2016). In this regard, the use of plant growthpromoting rhizobacteria (PGPR) is a viable option to assist phytoextraction of $\mathrm{Cd}$ (Mengoni et al., 2010; Sessitsch et al., 2013). Moreover, the efficiency of the phytoextraction process can also be improved through the inoculation of PGPR's (Dourado et al., 2013; Khan and Lee, 2013; Sessitsch et al., 2013).

The aim of this study was to analyze the effect of bacterization of carpet grass (Axonopus affinis) seeds with a plant growth promoting rhizobacteria and EDTA on germination and seedlings response in presence of cadmium.

\section{Materials and Methods}

\section{Inoculum preparation of the employed rhizobacteria}

A siderophore producing rhizobacteria strain was employed as inoculant: Pseudomonas sp. strain Sp7E isolated from the rhizosphere of Viguiera dentata (Cav.) Spreng, by Melo et al., (2011). Bacterial inoculum was obtained from the rhizobacteria strain cultured on plates with LuriaBertani (LB) agar medium for $48 \mathrm{~h}$ at $28^{\circ} \mathrm{C}$. Calibrated loops (1/100 cells) were re-suspended in a nefelometric flask with $25 \mathrm{~mL}$ of LB liquid medium, incubated in a shaker incubator at $28^{\circ} \mathrm{C}$ for $24 \mathrm{~h}$. Later, the inoculum was finally adjusted to an optical density of $5 \times 10^{7} \mathrm{CFU} / \mathrm{mL}$ for the bioassays.

\section{Plant growth promoting effect on Axonopus affinis seeds inoculated with the rhizobacteria}

$30 \mathrm{~g}$ of commercially obtained certified seeds of Axonopus affinis (Chase) were surface-sterilized with $10 \%$ sodium hypochlorite and then thoroughly rinsed with sterile distilled water. These sterilized seeds were incubated for $30 \mathrm{~min}$ at room temperature in either $10 \mathrm{~mL}$ of sterile distilled water as a blank control or a bacterial suspension of Pseudomonas sp. strain Sp7E in distilled water of 5 $\times 10^{7} \mathrm{CFU} / \mathrm{mL}$. Fifteen seeds of this plant species, treated and non-treated with rhizobacteria, were placed separately in baby food flasks with Magenta SIGMA caps with $25 \mathrm{~mL}$ of mineral medium containing: $0.20 \mathrm{M} \mathrm{NH} \mathrm{H}_{2} \mathrm{PO}_{4}, 1.15 \mathrm{M} \mathrm{Ca}\left(\mathrm{NO}_{3}\right)_{2}$, $0.40 \mathrm{M} \mathrm{MgSO}_{4} \cdot 7 \mathrm{H}_{2} \mathrm{O}, 1.2 \mathrm{M} \mathrm{KNO}_{3}, 1.2 \times 10^{-2} \mathrm{M}$ $\mathrm{H}_{3} \mathrm{BO}_{3}, 1.2 \times 10^{-4} \mathrm{M} \mathrm{CuCl}{ }_{2} \cdot \mathrm{H}_{2} \mathrm{O}, 2.3 \times 10^{-3} \mathrm{M}$ $\mathrm{ZnCl}_{2}, 4.4 \times 10^{-4} \mathrm{M} \mathrm{MnCl}_{2} \cdot 4 \mathrm{H}_{2} \mathrm{O}, 6 \times 10^{-6} \mathrm{M}$ $\mathrm{Na}_{2} \mathrm{MoO}_{4} \cdot \mathrm{H}_{2} \mathrm{O}, \mathrm{pH}=+6.0$ with $3.5 \mathrm{~g} / \mathrm{L}$ of phytagel (SIGMA Co.). Supplemented in each case with $1 \mathrm{mM} \mathrm{Cd}\left(3 \mathrm{CdSO}_{4} \cdot 8 \mathrm{H}_{2} \mathrm{O}\right)$ and $5 \mathrm{mM}$ Fe-EDTA solution $\left(7.1 \times 10^{-3} \mathrm{M} \mathrm{FeSO}_{4} \cdot 7 \mathrm{H}_{2} \mathrm{O}\right.$ and $7.2 \times 10^{-3} \mathrm{M}$ $\mathrm{Na}_{2}$-EDTA salt), according to the experimental conditions established: inoculated with the rhizobacteria $(\mathrm{Rb})$ only with metal $(\mathrm{Cd})$, inoculated with the rhizobacteria and in presence of the metal $(\mathrm{CdRb})$, only in presence of the chelating agent (EDTA), inoculated with the rhizobacteria and in presence of the chelating agent (EDTARb), in presence of the metal and chelating agent (CdEDTA) and finally, inoculated with the rhizobacteria and in presence of metal and chelating agent (CdEDTARb). Control experiments (C) were performed without the inoculum, metal and chelating agent. All the experiments were developed in sterile conditions and performed by quintuplicate. Experimental units were kept at $+36^{\circ} \mathrm{C}$ in a growth chamber with a $12: 12$ photoperiod for twelve days.

\section{Growth evaluation of Axonopus affinis seedlings}

Epicotyl and radicle of seedlings were separated after twelve days and measured. Growth of seedlings was evaluated by their morphological characters as follows: germination percentage $(\%)$, seedling length and the Vigor Index (VI) was calculated using the formula of Cokkizgin and Cokkizgin (2010): VI = [MEL + MRL] $\mathrm{x}$ GP; where, MEL is the mean epicotyl length, MRL is the mean root length and GP is the germination percentage $(\%)$. 
Tolerance Index (TI) was calculated by using the formula of Wilkins (1978) and Burd et al., (1998), considering the length of epicotyl and root of the seedlings as follows: ETI = LEm/LEc; and RTI = LRm/LRc, where, ETI is the Epicotyl Tolerance Index, LEm the mean of epicotyls length of seedlings grown in the presence of cadmium and LEc is the mean epicotyls length of seedlings grown without the metal; the same for Root Tolerance Index (RTI).

Experiments with the rhizobacteria added were also evaluated using this formula: ETI = LErb /LEc, where LErb is the mean epicotyls length of seedlings inoculated with rhizobacteria and LEc is the mean epicotyls length of seedlings without the inoculum, same for Root Tolerance Index (RTI).

Toxicity of experimental conditions to Axonopus affinis seedlings, was measured according to BagurGonzález et al., (2011), by the Normalized Residual Percentage of Germinated Seeds Index (NRPGI) following the equation: NRPGI = Gexp-Gc/Gc Where, Gexp is the \% average of germinated seeds in experimental conditions tested $(\mathrm{Rb}, \mathrm{Cd}, \mathrm{CdRb}$, EDTA, EDTARb, CdEDTA, CdEDTARb), and Gc is the $\%$ average of germinated seeds in control condition and by the Normalized Residual Elongation Root Index (NRERI) following the equation:

NRERI = REexp-REc/REc Where, REexp is the average length of the root seedlings in experimental conditions tested and REc is the average length of the root seedlings in control condition. BagurGonzález et al., (2011) noted that the employ of these indices allows the analysis in this study of the toxicity produced by the metal, rhizobacteria and chelating agent tested; with values between -1 (maximum phytotoxicity) to $>0$, in a scale proposed by these authors that gives a good classification of this effect: A values $=0$ to -0.25 (low toxicity), $\mathrm{B}$ values $=-0.25$ to -0.5 (moderate toxicity), $\mathrm{C}$ values $=-0.5$ to -0.75 (high toxicity) and $\mathrm{D}$ values $=-0.75$ to -1 (very high toxicity); values $>0$ indicated a stimulation of growth determined as hormesis effect.

\section{Statistical analysis}

All data obtained were analyzed by one-way analysis of variance and the mean differences were compared applying a Tukey-Kramer Method using the statistics program Graph Pad Instat Ver. 2.03. A numerical comparative analysis considering the experimental conditions except the control was done; a distance matrix was built using the conventional standard distance coefficient, a phenogram was build using the unweighted pair group method of arithmetic averages (UPGMA) method and correlation coefficient of Pearson was obtained using the NTSyS-PC version 2.11T (Numerical Taxonomy and Multivariate Analysis System) software.

Principal Component Analysis (PCA) were done with matrix data set of ETI, RTI, GP, VI, NRPGI, NRERI, epicotyl length average (ELA) and root length average (RLA); employing the Pearson correlation, with PAST (Paleontological Statistics Software Package) Ver. 2.17b.

\section{Results and Discussion}

\section{Effect of bacterized seeds on seedlings of Axonopus affinis growth promotion}

Seed quality implicates viability and vigor; viability refers to the ability of a seed to germinate and produce a normal seedling and vigor is the sum total of those properties of the seed which determine the level of activity and performance of the seed during germination and seedling emergence (Afrakhteh et al., 2013). Values of Vigor Index (VI) represented the relationship between the seedlings growth (epicotyl and root lengths) and the germination percentage obtained (Table 1). In this study, results showed firstly the effect of bacterization of seeds and secondly, the seedlings growth promotion.

Germination percentage of $A$. affinis seeds, showed a particularly positive effect of $\mathrm{Cd}$ on it (94.65\%), where the bacterized effect of the seeds by itself produce a diminished percentage of germination; 
according to the obtained response: control $>\mathrm{Cd}>$ $\mathrm{CdRb}>\mathrm{CdEDTARb}>\mathrm{CdEDTA}>\mathrm{EDTA}>\mathrm{Rb}>$ EDTARb. Regarding to Vigor Index (VI), the particularly response of $A$. affinis seedlings showed a positive effect of $\mathrm{Cd}$ and rhizobacteria only with the highest values of 530 to 392; compared to control seedlings (632.07). Experiments with the chelating agent added showed a decrease in seedlings vigor (342 to 205).

In epicotyl and root lengths of A. affinis seedlings, the bacterization of seeds with Pseudomonas sp. strain Sp7E, cause a decrease on both morphological parameters (Figs. 1a and 1b).

The epicotyl growth was maintained by the presence of $\mathrm{Cd}$ and rhizobacteria; between them, only the metal promoted it, but with a slightly diminish compared to control seedlings. There was a remarkable effect of the presence at first sight of EDTA; that reduced the promotion of epicotyl and root length compared to control seedlings; with a little increase in seeds that were bacterized and added with $\mathrm{Cd}$ and EDTA.

Growth response of $A$. affinis seedlings: phytotoxicity of the experimental conditions tested

The response against the metal presence, was determined by the ETI and RTI (Table 2), against inoculated seeds and $\mathrm{Cd}(\mathrm{CdRb})$ where experiments with $\mathrm{Rb}$ and $\mathrm{CdRb}$ showed the highest values of tolerance for epicotyl (0.86 and 0.79) and roots (0.77 and 0.56), respectively. Only the tolerance against $\mathrm{Cd}$ presence showed a similar value for both structures ( 0.88 and 0.57 , respectively). With the same values in $\mathrm{Cd}$ and CdEDTA experiments (0.57). The results of these experiments presented as tolerance index, has an important notation about the values obtained; as Burd et al., (1998) mention; a TI value of 1.0 indicates that the experiment condition was not inhibitory, whereas a value of 0.1 indicates this was only $10 \%$ of the growth of control seedlings.

These responses were agree with the analysis done of the phytotoxic effect of $\mathrm{Rb}, \mathrm{Cd}$ and EDTA, by the determination of the NRERI and NRPGI indices; where according to Bagur-González et al., (2011) (Table 3), experiments that influenced root length were characterized according to "A category" (low toxicity): $\mathrm{Cd}>\mathrm{Rb}$, "B category" (moderate toxicity): EDTA $>\mathrm{CdRb}$ and " $\mathrm{C}$ category" (high toxicity): CdEDTA $>$ EDTARb $>$ CdEDTARb.

Experiments that affect seed germination were grouped only in two categories: "A" (low toxicity): EDTA > CdEDTA > CdEDTARb > CdRb > Cd and "B" (moderate toxicity): EDTARb $>\mathrm{Rb}$.

\section{Relationship between experimental conditions and $A$. affinis seedlings evaluated parameters}

According to the multivariate analysis, Fig. 2 shows the association of groups according with the nature of the responses obtained for each experiment; where two groups forming at first:

Group I made only by CdEDTA and EDTARb experiments and the rest of them comprise the group II; in this group the $\mathrm{Cd}$ presence is separate of the rest (group IIa) and the other experiments forming the group IIb by CdEDTARb as one group and the cluster made by $\mathrm{Rb}$ and $\mathrm{CdRb}$ experiments.

These analysis demonstrate that the experiments established with the $\mathrm{Cd}$ and/or seeds bacterization with Pseudomonas sp. strain Sp7E; showed a particularly response compared to the experiments where EDTA was present.

Burd et al. (1998) mentioned that regardless of the precise mechanism used by the bacterium to protect plants, the experiments with plant seedlings and suggest bacteria may eventually find a use in the development of phytoremediation strategies; these responses can be related to the fact that depending on the conditions, the stimulation of plant growth can ensure by the phytohormones produced (particularly indole acetic acid: IAA) by PGPR's bounded to the seeds or roots (Patten and Glick, 2002), altering the hormonal balance within the affected plant. 
Table 1. Determination of Vigor Index of Axonopus affinis seedlings.

\begin{tabular}{lllll}
\hline Experiments & Epicotyl length average & Root length average & $\begin{array}{l}\text { Germination } \\
\text { percentage }\end{array}$ & Vigor Index \\
\hline $\mathrm{C}$ & 4.71 & 1.87 & 95.98 & 632.07 \\
$\mathrm{Rb}$ & 4.09 & 1.45 & 70.73 & 392.63 \\
$\mathrm{Cd}$ & 4.16 & 1.44 & 94.65 & 530.33 \\
$\mathrm{CdRb}$ & 3.74 & 1.06 & 89.3 & 429.64 \\
$\mathrm{EDTA}$ & 2.93 & 0.94 & 78.59 & 305.04 \\
$\mathrm{EDTARb}$ & 2.37 & 0.82 & 63.99 & 205.14 \\
$\mathrm{CdEDTA}$ & 2.7 & 0.71 & 79.93 & 273.45 \\
$\mathrm{CdEDTARb}$ & 3.21 & 0.83 & 85.33 & 345.22 \\
\hline
\end{tabular}

Table 2. Determination of Tolerance Index of Axonopus affinis.

\begin{tabular}{|c|c|}
\hline \multicolumn{2}{|c|}{ Inoculated with rhizobacteria $+C d$} \\
\hline Experiments & ETI \\
\hline $\mathrm{Rb}$ & 0.869 \\
\hline $\mathrm{CdRb}$ & 0.794 \\
\hline EDTARb & 0.505 \\
\hline CdEDTARb & 0.681 \\
\hline Experiments & $R T I$ \\
\hline $\mathrm{Rb}$ & 0.775 \\
\hline $\mathrm{CdRb}$ & 0.569 \\
\hline EDTARb & 0.433 \\
\hline CdEDTARb & 0.444 \\
\hline \multicolumn{2}{|c|}{ Only with Cadmium presence } \\
\hline Experiments & ETI \\
\hline $\mathrm{Cd}$ & 0.883 \\
\hline CdEDTA & 0.574 \\
\hline Experiments & RTI \\
\hline $\mathrm{Cd}$ & 0.769 \\
\hline CdEDTA & 0.382 \\
\hline
\end{tabular}

Table 3. Determination of NRERI and NRPGI indices of Axonopus affinis seedlings.

\begin{tabular}{ll}
\hline Experiments & NRERI Index \\
\hline $\mathrm{Rb}$ & $\mathrm{A},-0.224$ \\
$\mathrm{Cd}$ & $\mathrm{A},-0.230$ \\
$\mathrm{CdRb}$ & $\mathrm{B},-0.430$ \\
$\mathrm{EDTA}$ & $\mathrm{B},-0.496$ \\
EDTARb & $\mathrm{C},-0.566$ \\
$\mathrm{CdEDTA}$ & $\mathrm{C},-0.617$ \\
CdEDTARb & $\mathrm{C},-0.555$ \\
\hline Experiments & $\mathbf{N R P G I}$ Index \\
\hline $\mathrm{Rb}$ & $\mathrm{B},-0.263$ \\
$\mathrm{Cd}$ & $\mathrm{A},-0.013$ \\
$\mathrm{CdRb}$ & $\mathrm{A},-0.069$ \\
EDTA & $\mathrm{A},-0.181$ \\
EDTARb & $\mathrm{B},-0.333$ \\
CdEDTA & $\mathrm{A},-0.167$ \\
CdEDTARb & $\mathrm{A},-0.110$ \\
\hline *Where: A $=0$ a -0.25 low toxicity, B= -0.25 a -0.5 moderate toxicity, C= -0.5 a -0.75 high toxicity, $\mathrm{D}=-0.75$ a -1.0 \\
very high toxicity y E $=>0$ hormesis (Bagur-González et al., 2011$).$
\end{tabular}




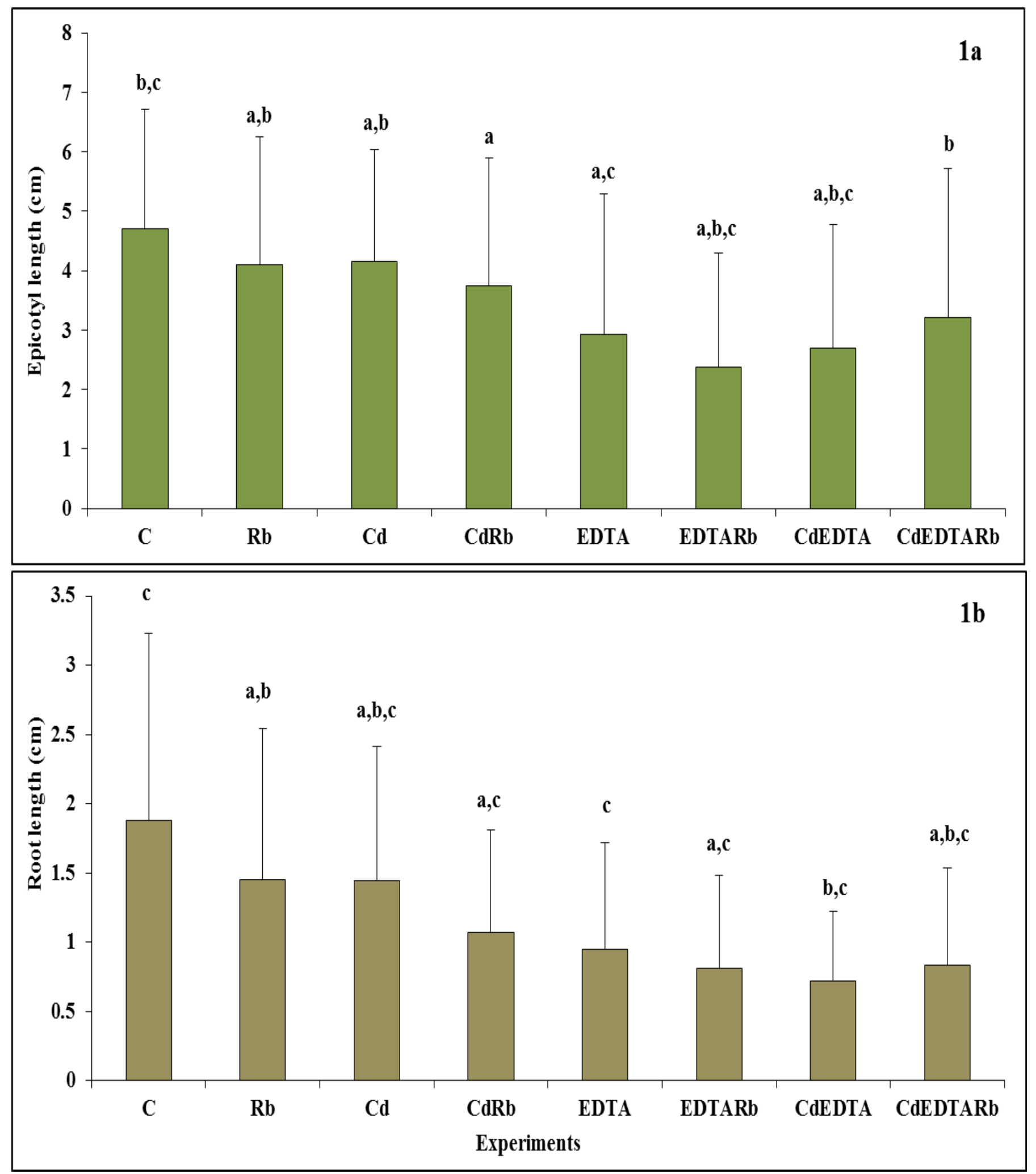

Fig.1: Axonopus affinis seedlings total length. 1a) epicotyl length and 1b) root length $(\mathrm{n}=15$. Mean values \pm S.D. from quintuplicates are given. The different lower-case letters shows the significant differences founded $(p<0.001))$. 


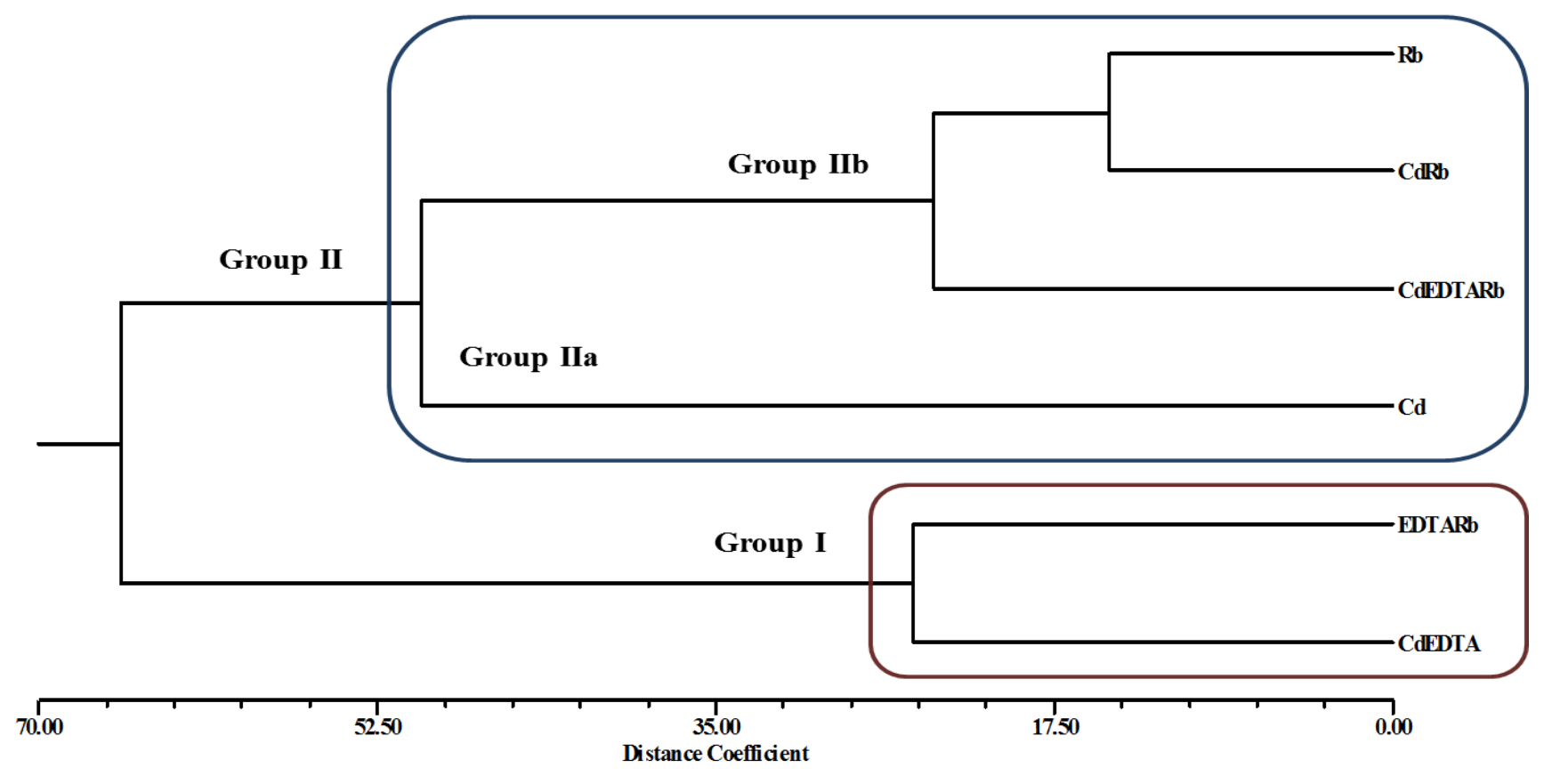

Fig. 2: Phenogram comparing the experimental conditions tested $(r=0.67)$.

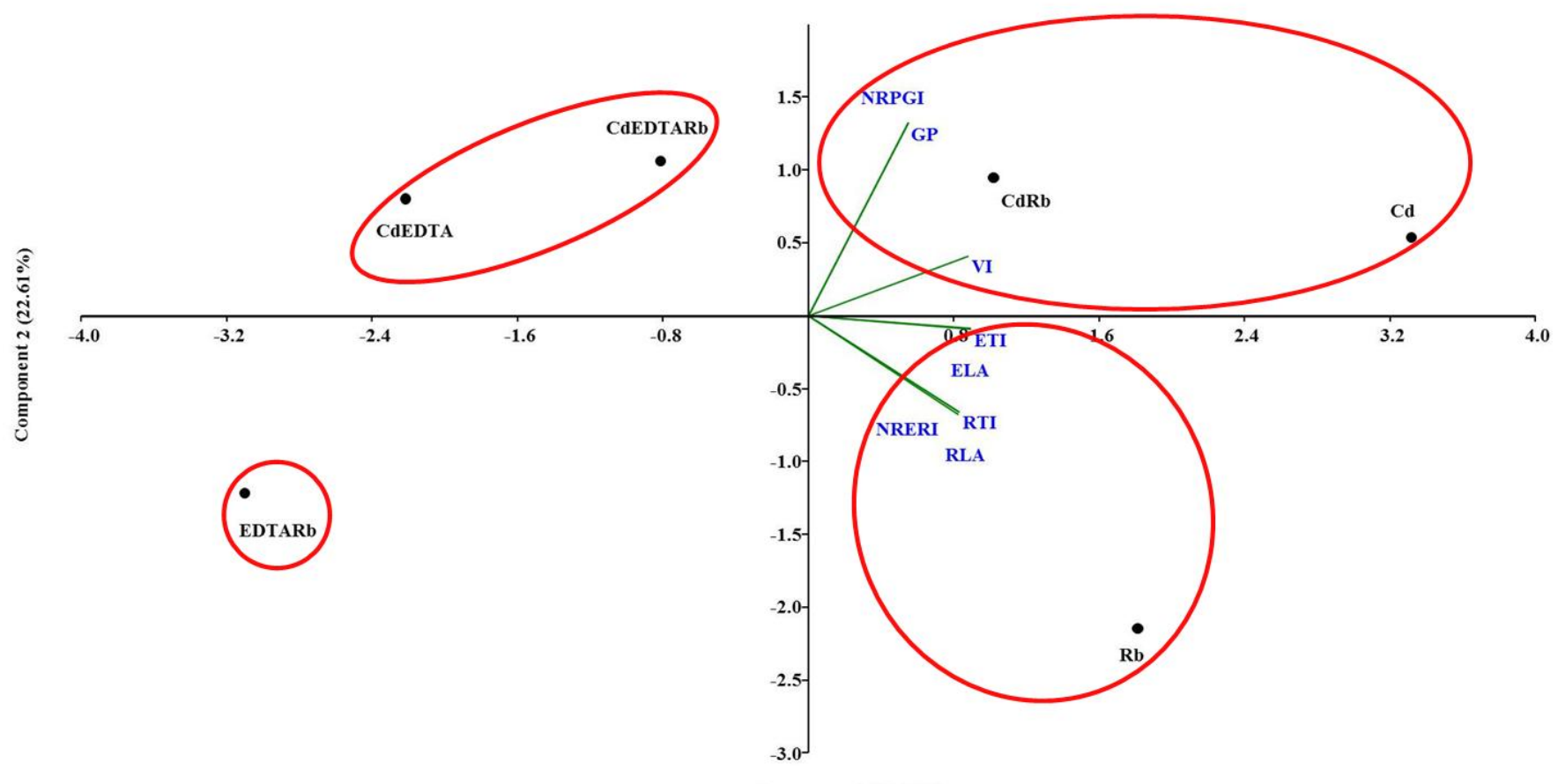

Component $1(76.27 \%)$

Fig. 3: Principal component analysis grouping the Axonopus affinis seedlings responses and experimental conditions tested. 
The PCA as a complement of the study, showed a good separation of experiments done and their parameters evaluated; according to Bagur-González et al. (2011), Fig. 3 allows to determine the level of phytotoxicity of the experiments; where negative Component 1 values (76.27\%) indicate a high level and its positive values a low level of phytotoxicity. In this study, the highest toxicity was founded in CdEDTA, CdEDTARb and EDTARb experiments, where EDTA has a pronounced negative effect. In this figure there is also a particularly negative association between the experiments of seeds inoculated with the rhizobacteria $(\mathrm{Rb})$ and the parameters: ELA, RLA, ETI, RTI and NRERI. With a positive effect in the relationship between $\mathrm{CdRb}$ and $\mathrm{Cd}$ experiments with GP, VI and NRPGI parameters.

Even Agbadah et al. (2016) investigated the effect of EDTA on germination, growth of Cd treated Zea mays L. and Vigna unguiculata L. species; results showed that the co-treatment of $\mathrm{Cd}$ and these plant species treated with $0.5 \mathrm{mM}$ and $1.0 \mathrm{mM}$ EDTA reversed the inhibition of growth rate; Ebrahimi (2013) showed that statistically EDTA affected the growth of Echinochloa crus galii related to its germination, root length, shoot length and biomass. EDTA $(10 \mathrm{mM} / \mathrm{Kg})$ treatments decreased the germination rates and percentages; these authors noted that this could be because EDTA elevates the bioavailability of heavy metals. Lian et al. (2007) reported that some studies found that in a certain EDTA concentrations it can strongly inhibited the plant growth.

Ştefan et al. (2008) reported that the delay in the germination of plant growth promoting rhizobacteria treated seeds can be explained regarding to two possible aspects; the inhibitory effect could be the result of an oxidative stress induced by the presence and activity of the PGPR's employed as seed inoculants and the second possible explanation is a competition for nutrient resources between seeds, seedlings and rhizobacteria. Special case was reported by Belimov et al. (2005), these authors mention that inoculations with strains having plant root elongation promoting (PREP) activity stimulated the root elongation in Cd-treated Brassica juncea seedlings as compared to $\mathrm{Cd}$-untreated seedlings.

In this study, the analysis done of Axonopus affinis by its morphological determinations showed the effect of different assisted phytoextraction agents that could be added to experimental conditions, in some way inhibited and/or promoted the first stage of development in this plant species. Although the seedlings of $A$. affinis grown in presence of $\mathrm{Cd}$ and inoculated seeds with Pseudomonas sp. strain Sp7E, do not shown a promotion with the rhizobacteria strain; these results demonstrated that the presence of the rhizobacteria maintained the growth of seedlings and tolerated the presence of the metal, including the adverse effects of EDTA; suggesting a synergistic effect between this plant species and microorganism.

\section{Acknowledgements}

Authors are grateful to the Research Projects SIPIPN: 20121516 and 20131494 of the Secretaría de Investigación y Posgrado del Instituto Politécnico Nacional, for providing the facilities to carry out this work and also wish to thank for the fellowships from Comisión de Operación y Fomento de Actividades Académicas (COFAA, I.P.N.), EDI (Estímulo al Desempeño de los Investigadores, I.P.N.) and SNI-CONACYT.

\section{References}

Afrakhteh, S., Frahmandfar, E., Hamidi, A., Ramandi, H.D., 2013. Evaluation of growth characteristics and seedling vigor in two cultivars of soybean dried under different temperature and fluidized bed dryer. Intl. J. Agri. Crop Sci. 5, 2537-2544.

Agbadah, E.E., Nwachukwu, K.C., Okoh M.P., 2016. Biochemical effects of ethylene diamine tetra-acetic acid (EDTA) on cadmium treated maize (Zea mays L.) and cowpea (Vigna unguiculata L.). Afr. J. Biotechnol.15, 593-600. Ahmad, I., Akhtar, M.J., Asghar, H.N., Ghafoor, U., Shahid, M., 2016. Differential effects of 
plant growth-promoting rhizobacteria on maize growth and cadmium uptake. J. Plant Growth Regul. 35, 303-315.

Araùjo, A.S.F., Sahyoun, F.K., Monteiro, R.T.R., 2001. Evaluation of toxicity of textile sludge compost on seed germination and root elongation of soybean and wheat. Rev. Ecosistema. 26, 117-119.

Bagur-González, M.G., Estepa-Molina, C., MartínPeinado, F., Morales-Ruano, S., 2011. Toxicity assessment using Lactuca sativa L. bioassay of the metal (loid) s As, $\mathrm{Cu}, \mathrm{Mn}, \mathrm{Pb}$ and $\mathrm{Zn}$ in soluble-in-water saturated soil extracts from an abandoned mining site. J. Soils Sediments. 11, 281-289.

Belimov, A.A., Hontzeas, N., Safronova, V.I, Demchinskaya, S.V., Piluzza, G., Bullitta, S., Glick, B.R., 2005. Cadmium-tolerant plant growth-promoting bacteria associated with the roots of Indian mustard (Brassica juncea L. Czern.). Soil Biol. Biochem. 37, 241-250.

Burd, G.I., Dixon, D.G., Glick, B.R., 1998. A plant growth-promoting bacterium that decreases nickel toxicity in seedlings. Appl. Environ. Microbiol. 64, 3663-3668.

Cokkizgin, A., Cokkizgin, H., 2010. Effects of lead $\left(\mathrm{PbCl}_{2}\right)$ stress on germination of lentil (Lens culinaris Medic.) lines. Afr. J. Biotechnol. 9, 8608-8612.

Di Salvatore, M., Carafa, A.M., Carratù, G., 2008. Assessment of heavy metals phytotoxicity next term using seed germination and root elongation tests: a comparison of two growth substrates. Chemosphere.73, 1461-1464.

Dourado, M.N., Martins, P.F., Quecine, M.C., Piotto, F.A., Souza, L.A., Franco, M.R., Tezotto, T., Azevedo, R.A., 2013. Burkholderia sp. SCMS54 reduces cadmium toxicity and promotes growth in tomato. Ann. Appl. Biol. 163, 494-507.

Ebrahimi, M., 2013. Effect of EDTA application on heavy metals uptake and germination of Echinochloa crus galii (L.) Beave in contaminated soil. Intl. J. Agri. Crop Sci. 6, 197-202.

Evangelou, M.W.H., Mathias, E., Schaeffer, A., 2007. Chelate assisted phytoextraction of heavy metals from soil. Effect, mechanism, toxicity and fate of chelating agents. Chemosphere. 68, 989-1003.

Grčman, H., Velikonja-Bolta, S., Vodnic, D., Leštan, D., 2001. EDTA enhanced heavy metal phytoextraction: metal accumulation, leaching and toxicity. Plant Soil 235,105-114.

Khan, A.L., Lee, I.J., 2013.Endophytic Penicillium funiculosum LHL06 secretes gibberellin that reprograms Glycine max L. growth during copper stress. BMC Plant Biol. 13, 86-100.

Li, W.Q., Khan, M.A., Yamaguchi, S., Kamiya, Y. 2005. Effects of heavy metals on seed germination and early seedling growth of Arabidopsis thaliana. Plant Growth Regul. 46, 45-50.

Lian, F., Zhao, S.L., Teng, M., Duo, L., 2007. Effects of EDTA on seed germination and seeding growth of annual ryegrass. Heilongjiang Animal Science and Veterinary Medicine 12, 62-64.

Mahmood, T., Islam, K.R., Muhammad, S., 2007. Toxic effects of heavy metals on early growth and tolerance of cereal crops. Pak. J. Bot. 39, 451-462.

Melo, M.R., Flores, N.R., Murrieta, S.V., Tovar, A.V., Zúñiga, A.G., Hernández, O.F., Mendoza, A.P., Pérez, N.O., Dorantes, A.R. 2011. Comparative plant growth promoting traits and distribution of rhizobacteria associated with heavy metals in contaminated soils. Int. J. Environ. Sci. Technol. 8, 807-816.

Mengoni, A., Schat, H., Vangronsveld, J. 2010. Plants as extreme environments? $\mathrm{Ni}$ resistant bacteria and Ni-hyperaccumulators of serpentine flora. Plant Soil. 331, 5-16.

Munzuroglu, O., Geckil, H., 2002. Effects of metals on seed germination, root elongation and coleoptile and hypocotyl growth in Triticum aestivum and Cucumis sativus. Arch. Environ. Contam. Toxicol. 43, 203-213.

Öncel, I., Keles, Y., Üstün, A.S. 2000. Interactive effects of temperature and heavy metal stress on the growth and some biochemical compounds in wheat seedlings. Environ. Pollut. 107, 315-320.

Patten, C.L., Glick, B.R., 2002. The role of bacterial indoleacetic acid in the development 
of the host plant root system. Appl. Environ. Microbiol. 68, 3795-3801.

Sessitsch, A., Kuffner, M., Kidd, P., Vangronsveld, J., Wenzel, W.W., Fallmann, K., Puschenreiter, M. 2013. The role of plant-associated bacteria in the mobilization and phytoextraction of trace elements in contaminated soils. Soil Biol. Biochem. 60,182-194.

Soudek, P., Katrušáková, A., Sedláček, L., Petrová, S., Kočí, V., Maršík, P., Griga, M., Vaněk, T. 2010. Effect of heavy metals on inhibition of root elongation in 23 cultivars of flax (Linum usitatissimum L.). Arch. Environ. Contam. Toxicol. 59,194-203.

Ştefan, M., Mihăşan, M., Dunca, S., 2008. Plant growth promoting rhizobacteria can inhibit the in vitro germination of Glycine max L. seeds. Analele Ştiinţifice ale Universităţii, Alexandru
Ioan Cuza", Secţiunea Genetică şi Biologie Moleculară. 9, 105-110.

Visioli, G., Conti, F.D., Gardi, C., Menta, C., 2014. Germination and root elongation bioassays in six different plant species for testing $\mathrm{Ni}$ contamination in soil. Bull. Environ. Contam. Toxicol. 92, 490-496.

Wang, W., Keturi, P.H., 1990. Comparative seed germination tests using ten plant species for toxicity assessment of metals engraving effluent sample. Water, Air, Soil Pollut. 52, 369-376.

Wang, W., Williams, J.M., 1990. The use of phytotoxicity tests (common duckweed, cabbage, and millet) for determining effluent toxicity. Environ. Monit. Assess. 14, 45-58.

Wilkins, D.A., 1978. The measurement of tolerance to edaphic factors by means of root growth. New. Phytol. 80, 623-633.

\section{How to cite this article:}

Corona-Álvarez, D., Guerrero-Zúñiga, L. A., Rodríguez-Dorantes, A., 2018. Comparison in growth parameters of the bacterization effect on Axonopus affinis seeds and EDTA against cadmium. Int. J. Curr. Res. Biosci. Plant Biol. 5(1), 25-34. doi: https://doi.org/10.20546/ijcrbp.2018.501.004 